\section{Histological Distribution of Anthocyanins in Anthurium Spathes}

\author{
Surawit Wannakrairoj' and 'Haruyuki Kamemoto' \\ Department of Horticulture, University of Hawaii, Honolulu, HI 96822
}

Additional index words. Anthurium andraeanum, flower color

Anthoeyanins are flavonoid pigments located in cell vacuoles responsible for most of the scarlet, orange, red, purple, and blue colors in plant organs (Hrazdina, 1982). Although the location of the anthocyanin-containing cells within the organ has been reported to play some role in coloration (Biran et al., 1974), the histology of anthocyanin accumulation has received relatively little attention. The present study explored the distribution of anthoeyanin in the spathes of several Anthurium species.

Anthurium species grown in the polypropylene shadehouse at the Univ. of Hawaii were used in this study. Freehand sections of fresh spathes were placed in deionized water before examination under a light microscope at $\times 100$. The spathe tissue layers were scored for cellular anthocyanins as follows: $0=$ the absence of anthocyanins, 1 = very few cells with anthocyanins, 2 = few cells with anthocyanins, $3=$ moderate number of cells with anthocyanins, $4=$ most cells with anthocyanins, and $5=$ all cells with anthocyanins.

The location of anthocyanin accumulation in spathes differed among Anthurium species (Table 1). In A. andraeanum of the section Calomystrium, anthocyanins were found exclusively in the hypodermal layers, just as reported by Higaki et al. (1984). In three other species belonging to the same section, anthocyanins were distributed in the hypodermic and mesophyll cells. None of the $A$. andraeanum individuals contained anthocy-

Received for publication 2 June 1989: Hawaii Institute of Tropical Agriculture and Human Resources Journal Series no. 3389. The cost of publishing this paper was defrayed in part by the payment of. page charges. Under postal regulations, this paper therefore must be hereby marked advertisement solely to indicate this fact.

'Former Graduate Research Assistant; presently Instructor, Kasetsart Univ., Bangkok 10900, Thailand.

'Emeritus Professor of Horticulture.

Section Belolonchium

A. cerrobaulense Matuda

Section Calomystrium

A. andraeanum Lind. ex André

A. formosum Schott.

A. kamemotoanum Croat

A. ravenii Croat \& Baker

A. lentii Croat \& Baker

Section Pachyneurium

A. coriaceum Endl.

A. plowmanii Croat

A. superbum Madison

A. watermaliense Bailey

Section Porphyrochitonium

A. amnicola Dressier

A. antioquiense Engler

A. bicollectivum Croat

A. friedrichsthalii Schott.

A. jefense Croat

A. wendlingerii Barroso

Section Urospadix

A. gladiifolium Schott. anins in the epidermal layers.

The distribution of anthocyanins in the lavender-flowered A. amnicola of the section Porphyrochitonium was restricted to the epidermal layers. The closely related A. antioquiense had a few pigmented cells in the abaxial epidermis and hypodermic. A. wendlingerii, also of the same section, showed anthocyanins in cells of all spathe tissues. Three other species in the same section had no anthocyanin in the epidermal layers. Porphyrochitonium is a large section with at least two intercrossable groups (Croat and Sheffer, 1983). One group included A. amnicola and $A$. antioquiense, which are crossable with members of the section Calomysrium.

In three of the four species examined in the section Pachyneurium, anthocyanins were concentrated in the adaxial epidermis. In contrast, A. coriaceum showed no anthocyanins in the epidermis and a high concentration of anthocyanins in the mesophyll layers. This result suggests a possible taxonomic divergence of $\mathrm{A}$. coriaceum in the section $\mathrm{Pa}$ chyneurium.

Even though few species were investigated, our results suggest that the histological distribution of anthocyanins might be valuable in establishing intrasectional species relationships.

\section{Literature Cited}

Biran, I., M. Robinson, and A.H. Halevy. 1974. Factors determining petal colour of Baccara roses. IL The effect of pigment concentration. J. Expt. Bet. 25:624-631.

Croat, T.B. and R.D. Sheffer 1983. The sectional groupings of Anthurium (Araceae). Aroideana 6:85-123.

Higaki, T., H.P. Rasmussen, and W.J. Carpen. 1984. A study of some morphological and anatomical aspects of Anthurium andraeanum Lind. Univ. of Hawaii HITAHR Res. Ser. 030.

Hrazdina, H. 1982. Anthocyanins, p. 135-188. In: J.B. Harborne and T.J. Mabry (eds.). The flavonoids: Advances in research. Chapman and Hall, London.

Table 1. Histological distribution of anthocyanin-containing cells in Anthurium spathes. ${ }^{2}$

\begin{tabular}{llc}
\hline \hline & \multicolumn{1}{c}{ Adaxial } & Abaxial \\
\cline { 2 - 3 } Species & Epidermis Hypodermic Mesophyll Epidermis Hypodermis Mesophyll \\
\hline
\end{tabular}

Section Digitinervium

$\begin{array}{ll}3 & 1 \\ 0 & 5 \\ 0 & 0 \\ 0 & 4 \\ 0 & 0 \\ 3 & 0 \\ 3 & \\ 0 & 1 \\ 5 & 0 \\ 5 & 4 \\ 5 & 0 \\ & \\ 5 & 0 \\ 1 & 1 \\ 0 & 3 \\ 0 & 0 \\ 0 & 1 \\ 5 & 4\end{array}$

30

$\begin{array}{lll}0 & 0 \\ 0 & 0 & 0 \\ 3 & 0 & 0\end{array}$

3
4

0

${ }^{2}$ Scoring of the presence of anthocyanins on cells of tissue layers: $0=$ no anthocyanins, $1=$ very few cells with anthocyanins, $2=$ few cells with anthocyanins, $3=$ moderate number of cells with anthocyanins, $4=$ most cells with anthocyanins, and $5=$ all cells with anthocyanins . 